\title{
Study on the Preparation and Water Retention Property of Water Retention Agent Based on Plant Ash
}

Jiaxing Wang, Yuxin Yang, Xinyu Bai, Yingmei Chen, Jiaxue Liu, Yafei Wang*

College of science, Heilongjiang Bayi Agricultural University, Daqing 163319, PR China

DOI: $10.36347 /$ sjavs.2020.v07i08.005

| Received: 18.08.2020 | Accepted: 25.08.2020 | Published: 28.08 .2020

*Corresponding author: Yafei Wang

\section{Abstract}

\section{Original Research Article}

In this paper, plant ash grains are used as raw materials to prepare water retention agent. The water absorbent property of water retention agent was evaluated, and the optimal condition of preparation was as follows: The mass ratio of polyacrylic acid monomer and plant ash was $3: 1$, the neutralization degree was $70 \%$, the mass ratio of evocating agent and monomer was $7.2 \%$, and water absorption rate was $562.4 \mathrm{~g} \cdot \mathrm{g}^{-1}$.

Keywords: Plant ash; water retention agent; water absorption property.

Copyright @ 2020: This is an open-access article distributed under the terms of the Creative Commons Attribution license which permits unrestricted use, distribution, and reproduction in any medium for non-commercial use (NonCommercial, or CC-BY-NC) provided the original author and source are credited.

\section{INTRODUCTION}

The quality of water is an important factor for human production and development. China is country short for fresh water. Especially these two years, because of the irregular climate and the imbalance of rainfall, the regions of drought for water are increasing, which has seriously impeded the development of agriculture. Water retention agent is one of the macromolecule materials, which could increase the property of absorbing water. It can improve the structure of soil, and decrease the loss of nutrients in soil [1]. From 1990s, there are hundreds of biological power plants emerging and a lot of straws are consumed. As of 2020, there are about 10000000 tons of plant ashes which exerts pressure on the surrounding environment [2]. How to handle these plant ashes effectively is very important, if the plant ashes could be made into water retention agent [3, 4], it would be highly profitable and it will be helpful in the management of environment.

\section{MATERIALS AND METHODS Materials}

Plant ashes were obtained from the residue of biological power plants. Analytical acrylic acid, acrylamide, ammonium peroxydisulfate, sodium hydroxide, N, N'- methylene bisacrylamide, and acetone were used. Constant temperature magnetic water bath, vacuum thermostatic drying box, ultrasonic cleaning machine was employed.

\section{Experiment methods}

Plant ashes were mixed with purified water to gelatinize for $2 \mathrm{~min}$ in a microwave ultrasound machine. The above solution was added into a threeneck flask, and then acrylamide and $\mathrm{N}, \mathrm{N}^{\prime}$ - methylene bisacrylamide, $0.2 \% \sim 0.5 \%$ ammonium peroxydisulfate were added successively, the mixture was heated at $70^{\circ} \mathrm{Cfor} 3 \sim 4 \mathrm{~h}$. The obtained polymer gel was washed by ethanol, and then soaked by acetone for $24 \mathrm{~h}$.

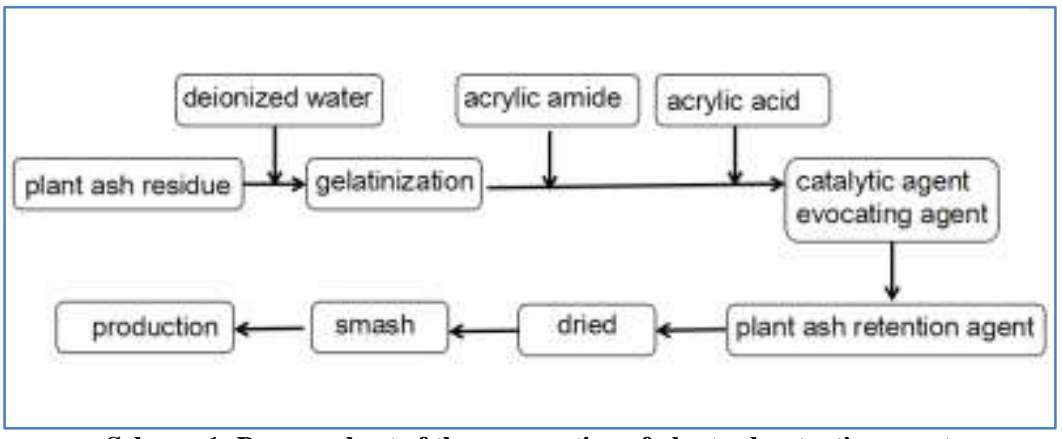

Scheme-1: Process chart of the preparation of plant ash retention agent 


\section{Water absorption test and repeated water absorption test of water retention agent Water absorption test}

$1.00 \mathrm{~g}$ of plant ash grains were mixed with $1000 \mathrm{~mL}$ purified water until the mass didn't change any more. The sample was filtered by standard sieve, and the mass off the sample after absorbing water was weighed.

\section{Water retention performance test}

Samples after the adsorption of water were dried in an oven at $50^{\circ} \mathrm{C}$, and the data was recorded every $2 \mathrm{~h}$.

\section{Repeated water absorption test}

Repeat the procedure of 1.3.2.

\section{Water retention performance test in sandy soil}

$1.00 \mathrm{~g}$ of plant ash water retention grains were mixed with $200 \mathrm{~g}$ dry sandy soil (which had been collected $5 \mathrm{~cm}$ beneath the earth's surface), after the deionized water absorption, the mass was recorded as $\mathrm{m}_{\mathrm{t}}$; and then the water retention agent was dried in an oven at $50{ }^{\circ} \mathrm{C}$, the mass was recorded as $\mathrm{m}_{\mathrm{i}}$ every $2 \mathrm{~h}$, until the mass didn't change any more.

\section{RESULTS AND DISCUSSION \\ Definition of the mass of plant ash}

The mass ratio of acrylic acid and acrylamide was $1: 1$, the mass ratio of evocating agent and monomer was $7.2 \%$; the mass ratio of crosslinking agent and monomer was $2.3 \%$, and different amount of plant ashes $(0.00 \mathrm{~g}, 1.00 \mathrm{~g}, 2.00 \mathrm{~g}, 3.00 \mathrm{~g}, 4.00 \mathrm{~g}, 5.00 \mathrm{~g}, 6.00 \mathrm{~g}$, and $7.00 \mathrm{~g}$ ) was added to prepare plant ash water retention agent. The water absorption rate was an important index to evaluate the water retention performance of water retention agent.

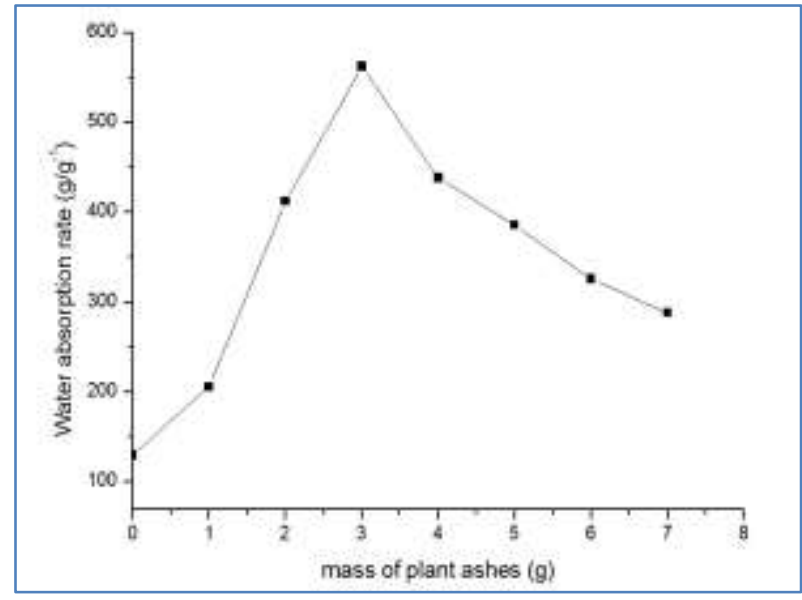

Fig-1: Effect of plant ash amount on water absorption rate

As shown in Fig.1, the water retention performance of the $3.00 \mathrm{~g}$ plant ash behaved best, and its deionized water absorption rate was $562.4 \mathrm{~g} \cdot \mathrm{g}^{-1}$.
Analysis of water retaining capacity

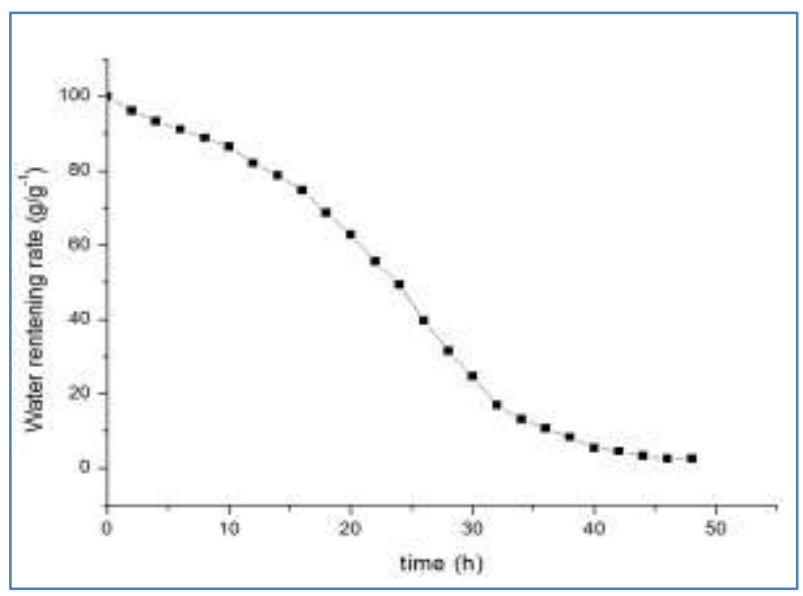

Fig-2: Water retaining rate of plant ash

Water retaining capacity could be evaluated by the deionized water absorption rate. The slower the water release rate was, the better the water retaining capacity would be. As shown in Fig.2, there were 3 stages in the water retaining procedure. The water retaining rate changed quickly in the $18 \mathrm{~h} \sim 34 \mathrm{~h}$; and it turned slowly in the $34 \mathrm{~h} \sim 48 \mathrm{~h}$. This explained that the plant ash could retain water when the water in soil was plentiful, and could drain away water slowly when there was drought.

\section{Analysis of repeated water retention rate}

The repeated water retention rate was another important index of evaluating the water retaining capacity. The water absorbent compound was tested according the procedure in 1.3.3.

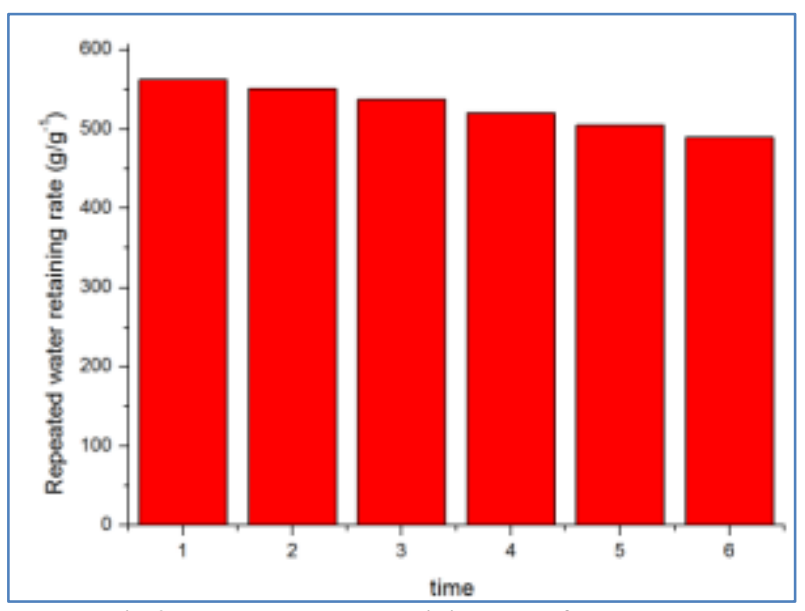

Fig-3: Repeated water retaining rate of plant ash

The repeated times of water retention agent could influence its life length. As shown in Fig.3, when the plant ash rentention agent was repeated for 6 times, the water absorption rate could reach $87.1 \%$. This result showed better repeated water retention ability, and the plant ash rentention agent could be used circularly. 


\section{Analysis of water retaining capacity in sandy soil}

If the plant ash rentention agent was fertilized in the soil, the water retention capacity would be different. The water rentention performance in soil influenced the application of water rentention agents. The reaction between water rentention agents and soil grains could prolong the water rentention capacity of soil grains, and the rate of water evaporation would decrease.

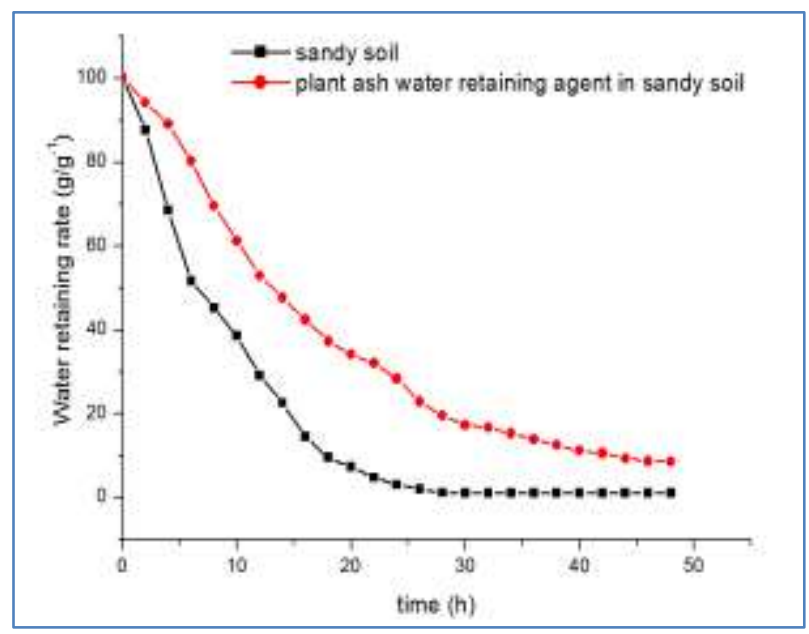

Fig-4: Comparison of water retaining rate between sandy soil and plant ashwater retaining agent in sandy soil

\section{RESULTS}

In summary, it is practicable to prepare rentention agent by plant ash. It is a good method to dispose the garbages of biological power plants. According to the detection indexes of absorption and retention properties, the optimum conditions are as follows: the mass ratio of polyacrylic acid monomer and plant ash was 3:1, neutralization degree was $70 \%$, the mass ratio of evocating agent and monomer was $7.2 \%$, and water absorption rate was $562.4 \mathrm{~g} \cdot \mathrm{g}-1$.

\section{REFERENCE}

1. Sun RJ, Li MY, Zhang JC, Zhu LJ. The Synthesis and Properties of the Modified Bentonite-Starch Absorbent Polymer. In Advanced Materials Research 2013 (Vol. 726, pp. 511-515). Trans Tech Publications Ltd.

2. Qu Changsheng, Li Bing, Wu haisuo. Controlling air pollution from straw burning in China calls for efficient recycling $[\mathrm{J}]$. Environment Science Techinology. 2012, 46(15):7934-7936.

3. Senff L, Ascenso G, Hotza D. Assessment of the single and combined effect of super absorbent particles and porogenic agents in nanotitaniacontaining mortars [J]. Energy \& Buildings. 2016, 127: 980-990.

4. Kono H, Zakimi M. Preparation, water absorbency, and enzyme degradability of novel chitin and cellulose/chitin-based superabsorbent hydrogels [J]. Journal of Applied Polymer Science. 2013, 128(1):572-581. 